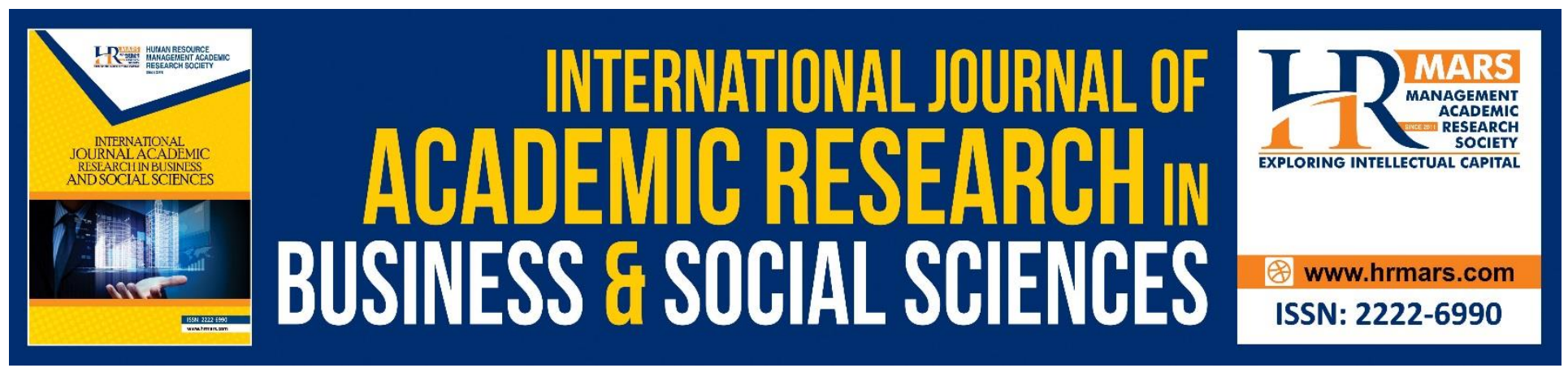

\title{
Nominal Group Technique Application on TPACK Element Requirements for Design and Technology Teachers in Malaysia
}

Fazidah Naziri, Mohamad Sattar Rasul \& Haryanti Mohd Affandi

To Link this Article: http://dx.doi.org/10.6007/IJARBSS/v9-i4/5810 DOI: $10.6007 /$ IJARBSS/v9-i4/5810

Received: 15 March 2019, Revised: 27 March 2019, Accepted: 1 April 2019

Published Online: 13 April 2019

In-Text Citation: (Naziri, Rasul, \& Affandi, 2019)

To Cite this Article: Naziri, F., Rasul, M. S., \& Affandi, H. M. (2019). Nominal Group Technique Application on TPACK Element Requirements for Design and Technology Teachers in Malaysia. International Journal of Academic Research Business and Social Sciences, 9(4), 8-15.

\section{Copyright: (C) 2019 The Author(s)}

Published by Human Resource Management Academic Research Society (www.hrmars.com)

This article is published under the Creative Commons Attribution (CC BY 4.0) license. Anyone may reproduce, distribute, translate and create derivative works of this article (for both commercial and non-commercial purposes), subject to full attribution to the original publication and authors. The full terms of this license may be seen

at: http://creativecommons.org/licences/by/4.0/legalcode

Vol. 9, No. 4, 2019, Pg. 8 - 15

http://hrmars.com/index.php/pages/detail/IJARBSS

JOURNAL HOMEPAGE

Full Terms \& Conditions of access and use can be found at http://hrmars.com/index.php/pages/detail/publication-ethics 


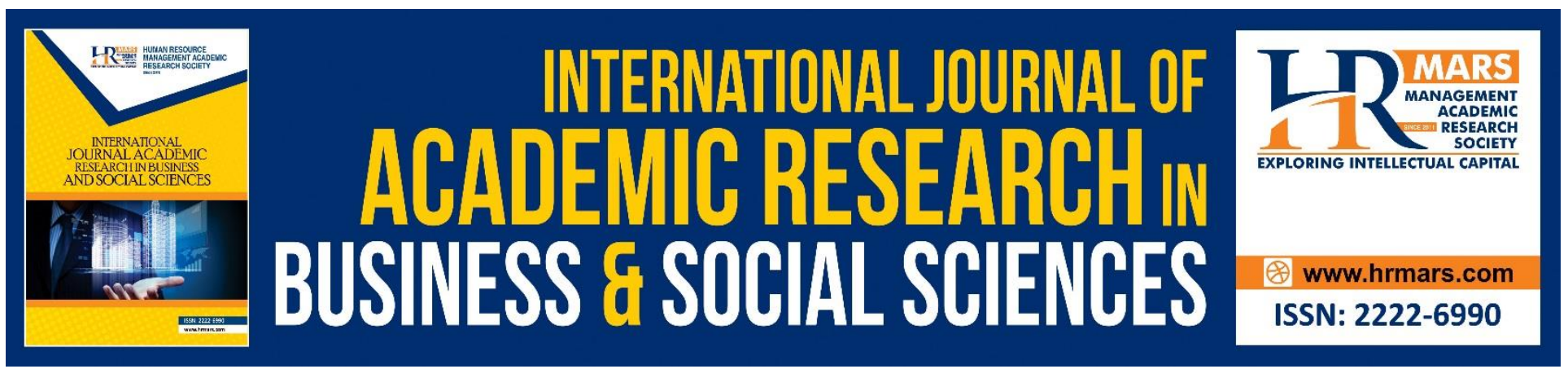

\title{
Nominal Group Technique Application on TPACK Element Requirements for Design and Technology Teachers in Malaysia
}

\author{
Fazidah Naziri \\ Faculty of Education, Universiti Kebangsaan Malaysia \\ Mohamad Sattar Rasul \\ Associate Professor (Dr), Faculty of Education, Universiti Kebangsaan Malaysia \\ Haryanti Mohd Affandi \\ Senior Lecturer (Dr), Faculty of Engineering and Built Environment, Universiti Kebangsaan Malaysia
}

\begin{abstract}
Today, the use of digital technology is a hot topic for debate especially in Malaysia's education system. Teachers become role models to students as catalysts in the modernization of Education, which in turn makes the learning environment more attractive and innovative. TPACK is the foundation of knowledge in communications information technology to make the world of teaching and learning fun and fun. The Nominal Group Technique is applied to assess the items available and needed to build a formative instrument of RBT's teacher's clinical supervision formative. Experts are selected based on expertise of public university lecturers, private university lecturers, teacher institute lecturers, Inspectorate and Quality Assurance officers, Curriculum Development Division, Principal, Senior Assistant Administration, Senior Co-Curriculum Assistant, State Primary Trainer and Distinguished Teacher for Design and Technology subjects. All experts are given a 5-member questionnaire and a group discussion is held for consensus. A total of 15 experts were selected in the Nominal Group Technique according to their expertise. Based on expert experience and research, they suggest items that need to be modified according to the requirements of each element being constructed. Next, this app has assessed and got expert deals in terms of the number of items selected within the TPACK framework. Finally, through the application of the Nominal Group Technique expert agreement in evaluating the items required in guiding the Design and Technology teachers acquired.
\end{abstract}

Keywords: Design and Technology Teacher, TPACK, Nominal Group Technique 


\section{Introduction}

Teachers are a very significant role model in high school level to make the teaching and facilitating process interesting and students are happy to learn. Professionalism can be measured through knowledge, skills and attitude of teachers from time to time based on teacher experience and learning. Changes in the Education system in Malaysia are now in line with the needs of future generations that are focused on digital technology. Information and communication technology in teacher teaching need to be strengthened through the $7^{\text {th }}$ shift of the Development and Education Plan 2013-2025 (KPM, 2013). Continuous and quality teacher guidance is needed to enhance the ability of teachers to use information and communication technology in teaching and facilitating. Efficiency which is a necessity in improving the skills of teachers is needed to realize the national aspiration of PPPM 2013-2025 to become a major platform for the development of the education system in Malaysia (KPM, 2013).

\section{TPACK}

One of the mediums to be the focus and guide to enhancing the ability of teachers in information and communication technology is the TPACK framework that was introduced by Mishra \& Koehler, (2006). Knowledge, pedagogy and technology become the main platform that needs to be expanded so that teachers can apply TPACK elements in teaching and facilitating in the classroom. According to Harris \& Hofer, (2011), the level of understanding of students becomes a key measure and teachers need to master knowledge, pedagogy and technology in total. Therefore, TPACK framework elements can be applied to individual teachers through supervisory supervision processes within a certain period of time. It is therefore desirable for the researcher to see the TPACK framework element requirements in the RBT teacher's formative supervisory instrument in Malaysia.

\section{Nominal Group Technique (NGT)}

The technique of a nominal group is a process in which it can generate and identify an issue. Therefore, this technique can be used to identify the importance of the elements needed in developing a product. Dobbie et al., (2004) states that this technique may reach agreement in viewing and evaluating the usability of a product being developed. The number of experts involved is 5 to 9 people (Ven \& Delbecq, 1971) while for Harvey \& Holmes (2012), a total of 6 to 12 people is required. There are also scholarly views such as Allen, Dyas and Jones (2004) which speaks experts of 912 people. The selected specialist must be involved with the teaching of design and technology subjects and experience in the process of clinical supervision of the teacher. Based on the argument of Dalkey \& Helmer (1963), the expert was selected to have a deep understanding and understanding of the research conducted.

\section{Statement of Problem}

Education transformation creates a new curriculum in the National Education system and teachers need to meet this challenge prudently. Recent studies show that TPACK elements are needed to improve teacher competence in teaching and learning (Hasniza, Faekah, \& Ariffin, 2016; Surif, Hasniza, \& Rohaya, 2012; Zainal et al., 2013). However, the TPACK element is not available in the design and technology design of the teacher in particular. The existence of a clinical instrument that 
enhances the quality of teaching of teachers should be done and created (KPM, 2013). In fact, a clinical supervisory instrument focusing on TPACK elements needs to be established to guide design and technology teachers to align with the 4th industry revolution. It is therefore desirable that this study be conducted in order to create a more focused supervisory instrument for teachers and design and technology subjects using TPACK elements.

\section{Research Objective}

Implementation of TPACK framework elements to improve teacher knowledge in terms of subject matter knowledge, teacher pedagogical knowledge and technology knowledge need to be created during the teacher's formative supervision. The main objectives of this study are:

i. Develop items for TPACK framework elements required by RBT teachers based on expert agreement via Nominal Group Technique.

\section{Methodology}

Nominal Group Technique is an option to get an expert agreement on the selection of items contained within the TPACK framework. The application of this technique is a collective discussion to resolve and decide on the problems encountered. In the discussion, all experts were given a set of questionnaires that resulted in all the items in the TPACK element. Experts discuss each item in the details involved in detail in which they reach agreement in terms of the language and purpose conveyed to suit the requirements of the instrument being constructed. Upon completion of all the items in each TPACK element discussed then each expert vote on the individual approval level. Value using 5-point Likert scale that is Very Disagreeable (STS), Disagree (TS), Disagree (KS), Agree (S) and Strongly Agree (ST). Likert scale points 1,2,3,4 and 5. Upon completion of individual polling experts, questionnaires were taken and carried out analysis of draws.

\section{Respondents and sampling}

The selection of samples and respondents is through the criteria in which the individual is experienced, has the expertise or the individual who can solve the problem of being a priority (Delbecq \& Ven, 1971). Critical aspects in Nominal Group Techniques are the selection of the number of respondents involved. Based on opinions expressed by Adler \& Ziglio, 1996) the number of experts ranging from 10 to 15 is permissible in terms of high uniformity and agreement. The environment of this number of experts is included in the recommendations by Jones and Twiss (1978) who need 10 to 50 specialists. However, this study selects 16 experts who have the following criteria:

i) Specialist who has served for more than 10 years in Technical and vocational field

ii) Experts who are directly involved with the teaching and supervision of RBT teachers at schools or higher education institutions.

iii) Experts who teach in RBT subjects and make supervision of teachers in service.

\section{Research Findings}

Expert agreement indicates that all TPACK elements are needed by school supervisors while guiding the design teachers and technology at school. During the clinical supervisory process, items in TPACK elements need to be refined so that teachers master the subject content, teaching pedagogy 
and technology used. The elements required by supervisors to guide design and technology teachers are shown in Figure 1.1 below.
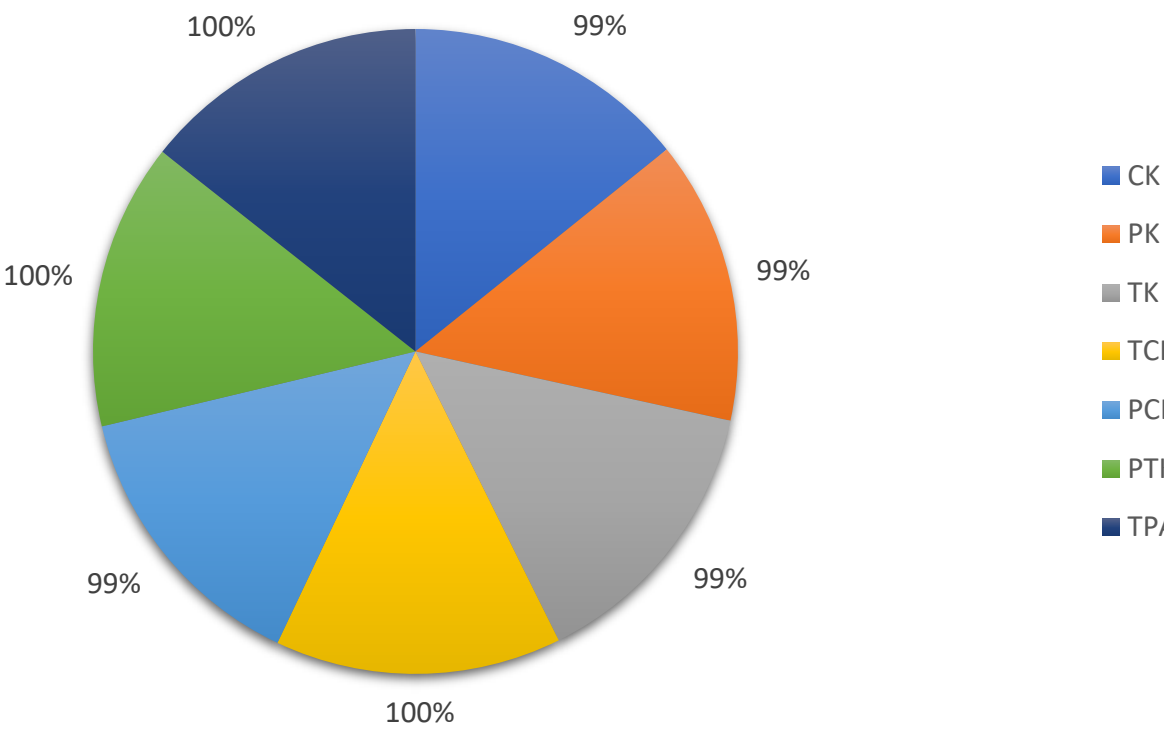

- PK

- TK

$\square$ TCK

$\square$ PCK

口PTK

- TPACK

Figure 1.1: NGT Consensus of TPACK elements

Based on Figure 1.1 above shows that all elements within the TPACK framework are in the range of $99-100 \%$. The TPACK elements decision range agreed upon in line with the scholarly view that the percentage of acceptance of an element measured has a percentage value of $\geq 70 \%$ (Deslendes et.al., 2010; Dobbie et.al., 2004).

The pedagogical element is the first choice for an expert agreement in which the teacher is the ultimate person to make the students' learning fun. Based on Figure 1.1, findings show experts agree on a $99 \%$ rate that pedagogical knowledge is an important element necessary in guiding design and technology teachers. Teachers' pedagogical knowledge can attract and motivate students to learn. Teachers can motivate students and diversify their approach, method and assessment to their students. The emphasis on the importance of motivating is emphasized by Aisyah et al., (2013) where motivational factors are a high aspect and have positive relevance in displaying students' emotionality.

The expert agreement on the second element is on the subject matter knowledge. This element clearly shows that as a teacher must master the knowledge of subjects taught. An expert agreement on this element is $99 \%$. Through items in this element, RBT teachers need to attend courses and look for learning resources to improve their knowledge. According to Bauer (2012) knowledge of subject matter content should be focused on pre-service curriculum and followed by learning during the course or training program. Since the transformation of Integrated Living Skills subjects into Design and Technology (RBT) subjects was introduced in 2017 it is desirable that this element be given special attention. Continuing from that, RBT teachers need to be guided on a 
continuous basis so that their knowledge will be enhanced through the Professional Learning Community (PLC) held at the school or the State Education Department level (JPN).

The third element that experts agreed was the pedagogy of content. Approaches, methods of teaching and subject knowledge should be integrated to encourage students' interest in classroom learning. The specialist agreement for this element is $99 \%$ where it exceeds the $70 \%$ item receiving range. The findings of this study are in line with empirical studies by Norashilah et al., (2015) which is the basis of content, activity in teaching premises as well as the use of approach diversity as an important aspect during teaching and learning.

Knowledge of pedagogical technology becomes the $4^{\text {th }}$ element agreed by experts to improve the potential of teachers in their teaching. All experts agree $100 \%$ of the elements of pedagogy technology knowledge required in clinical supervision of teacher. The choice of appropriate technology equipment and software is a necessity for improving student understanding. The findings of this study correspond to Ahmad Mustafa (2016) whose training in teacher service can enhance the knowledge and skills of information and communication technology teachers Lux et al., (2011) states that the development of professionalism of teachers should be emphasized in the aspect of integrating information and communication technology in their teaching so that a course attended is meaningful. And quality. Quality teachers are described as those who are confident in themselves during the teaching and facilitating process. Studies by Agena, Clemino, Linatoc, Manalo, \& Laguador, (2017) show that students with higher communication skills are more confident in giving the next idea of self-improvement. Therefore, through the application of TPACK elements, teachers share their ideas and views in the classroom discussion.

The fifth element that reaches the agreement between experts is the element of technological knowledge. Teachers need to have basic knowledge of technology and constantly renew and keep up with current developments in the digital world. Expert agreement indicates that 99\% of them agree that the element of technological knowledge is important in guiding the teacher. The need for the element answers questions from the study by Mustafa (2016) and Idris (2013) where the level of knowledge of teacher technology is moderate. As such, this element needs to be emphasized by experts to design and technology teachers to be able to learn and apply new technologies.

In addition, $100 \%$ expert agreement is obtained in the 6th element of content technology knowledge. The items in this element emphasize the need for RBT teachers to use the software, equipment and the use of information technology in instilling students' understanding of learning. Design and technology teachers need to explore the equipment or software of the technology that can meet the needs of each subject matter for the lesson to be more exciting and fun. The need for this element is evidenced by the findings of the study (Zainal et al., 2013) where rapid transformation in the digital world needs to support the technological know-how in line with the era's circulation. The suitability of the equipment used should be in line with the changes in the content of the lessons learned (Talib, Yassin, Nasir, \& Bunyamin, 2016). Therefore, the need for this element becomes an important aspect in guiding RBT teachers in Malaysia.

Finally, the element of integration between the knowledge of pedagogical technology of content in which the teacher must learn it is agreed by experts as much as $100 \%$. This element is focused on the specialists involved so that teachers can refer sources or individuals to improve their 
knowledge in technology integration. The items needed in this element are supported by Reyes, Reading, Doyle, \& Gregory, (2017) where teachers are less concerned with the effectiveness of their teaching through the selection of technology and the integration of the subjects causing them to be unattractive and effective. He adds that this element takes a long time to be understood and adapted to the subject matter. Therefore, the need for this element is indispensable in guiding clinical design and technology teachers so that teachers' learning process is continuous and consistent. Overall, the TPACK element has been seriously discussed and the agreement shows that its implementation still needs to be upgraded in schools (Voogt \& McKenney, 2017).

\section{Conclusion}

Discoveries through the application of Nominal Group Technique a group of experts reached an agreement of $100 \%$. This proves that experts agree that TPACK elements need to be present in the process of clinical supervision of design and technology teachers. The results of this study suggest that TPACK elements should be included in the RBT teacher's clinical procurement instrument so that competence in terms of knowledge, pedagogy and teacher technology is constantly enhanced in order to realize the transformation of the curriculum in the Malaysian education system. The advanced education system with high teacher professionalism needs to be in tandem with technological advances in the 4th industry revolution.

Contribution

This element has been discussed long ago and in this study the agreement of a group of experts agrees that the components contained within the TPACK framework are essential in teacher compatibility. This study proves that Shulman's theory, (1987) is the basis of the TPACK framework, thus contributing to the supervision of design and technology teachers in Malaysia. The transformation in the curriculum certainly impacts the teacher's knowledge of the TPACK element to add the teacher's existing knowledge with new knowledge about technology and integration among them.

\section{Corresponding Author}

Associate Professor Dr Mohammad Sattar Rasul, Faculty of Education, Universiti Kebangsaan Malaysia. Email: drsattar@ukm.edu.my

\section{References}

Adler, M. \& Ziglio, E. (1996). Gazing into the oracle: the Delphi method and its application to social policy and public health. London: Jessica Kingsley Publishers.

Mustafa, A. H. M. (2016). Integration of information and communication technology (TMK) integration with content pedagogy (PTPK) knowledge, learning styles and trust of Integrated Living Skills teachers. Universiti Kebangsaan Malaysia.

Allen, J., Dyas, J., Jones, M. (2004). Building consensus in health care: aguide to using the nominal group technique. British Journal of Community Nursing, 9(3), 110-114.

Dalkey, N. C., \& Helmer, O. (1963). An experimental application of the Delphi method to the use of experts. Management Science, 9(3), 458-467. 
Delbecq, A. L., \& Ven, D . V. A. H. (1971). A Group Process Model for Problem Identification and Program Planning. The Journal of Applied Behavioural Science, 7 (4), 466-492. https://doi.org/10.1177/002188637100700404

Deslendes, S. F., Corina Helena Figueira Mendes, C.H.F., Pires, T.O., \& Campos, D.S. (2010). Use of Nominal Group Technique and the Delphi Method to draw up evaluation indicators for strategies to deal with violence against children and aolescents in Brazil. Rev. Bras. Saude Matern. Infant, 10(1), 29-37.

Dobbie, A., Rhodes, M., Tysinger, JW. \& Freeman, J. (2004). Using a Modified Nominal Group Technique As a Curriculum Evaluation Tool, Family Medicine, 36(6), 402-406.

Harris, J. B., \& Hofer, M. J. (2011). Technological pedagogical content knowledge (TPACK) in action: A descriptive study of secondary teachers' curriculum-based, technology-related instructional planning. Journal of Research on Technology in Education, 43 (3), 211-229. https://doi.org/10.1080/15391523.2011.10782570

Harvey, N. \& Holmes, C. A. (2012). Nominal group technique: An effective method for obtaining group consensus. International Journal of Nursing, 18, 188-198.

Idris, N. (2013). Research in Education. Mc Graw Hill Education (2nd ed., Vol. 2). Kuala: McGraw-Hill Education (Malaysia) Sdn Bhd.

https://doi.org/10.1017/CBO9781107415324.004

KPM. (2013). Malaysian Education Development Plan (PPPM) 2013-2025. Kpm. https://doi.org/10.1016/j.tate.2010.08.007

Lux, N. J., Bangert, A.W., \& Whittier, D.B. (2011). The development of an instrument to accespreservices teacher's technological pedagogical content knowledge. Journal Educational Computing Research 45 (4): 415-431.

Mishra, P., \& Koehler, M. J. (2006). Technological pedagogical content knowledge: A framework for teacher knowledge. Teachers College Record. https://doi.org/10.1111/j.1467-9620.2006.00684.x

Reyes, V. C., Reading, C., Doyle, H., \& Gregory, S. (2017). Integrating ICT into teacher education programs from a TPACK perspective: Exploring perceptions of university lecturers.Computers and Education, 115, 1-19.

https://doi.org/10.1016/j.compedu.2017.07.009

Talib, N., Yassin, S. F. M., Nasir, M. K. M., \& Bunyamin, M. A. (2016). Integrating Technological Pedagogical and Content Knowledge in Computer Programming Courses: Issues and Challenges. Journal of Advanced Research Design, 27 (1), 1-15. Retrieved from http://www.akademiabaru.com/doc/ARDV27_N1_P1_13.pdf

Voogt, J., \& McKenney, S. (2017). TPACK in teacher education: are we preparing teachers to use technology for early literacy? Technology, Pedagogy and Education, 26 (1), 69-83. https://doi.org/10.1080/1475939X.2016.1174730

Zainal, N., Ibrahim, N. H., Surif, J., Mohktar, L. E., Farahwahidah, N., \& Rahman, A. (2013). Knowledge Pedagogical Knowledge Practices (PPK) Among the Chemistry Lecturers of Universiti Teknologi Malaysia, (Isqae), 154-165. 